\title{
Dramaturgia sztuki
}

ABSTRACT. Krajewska Anna, Dramaturgia sztuki [The dramaturgy of art]. „Przestrzenie Teorii” 31. Poznań 2019, Adam Mickiewicz University Press, pp. 7-12. ISSN 1644-6763. DOI 10.14746/ pt.2019.31.0.

In this Introduction, the author discusses the other articles contained in this volume and attempts to present the processess involved in art as stage preformance of both human and non-human actors. She not only examines the objects and persons but also aesthetic categories and the mechanisms involving categories in art. The author proposes a new language that allows for the description of art as a phenomenon of entangled objects, subjects, media, processes and events.

KEYWORDS: dramaturgy of art, human and non-human actors, entangled objects

Na kolejny, 31. numer „Przestrzeni Teorii” składają się teksty, które pisane były w większości z myśla o odpowiedzi na zaproponowane przez Redakcję prowokacyjne hasło: Sztuka bez granic. Wezwanie prowokacyjne, dlatego że granice sztuki zawsze, w każdej epoce, były w rozmaity sposób przekraczane, ale bardziej niż stwierdzenie oczywistego zjawiska interesujące dla nas było zebranie wypowiedzi prezentujacych różne podejścia do tego problemu. Poza ogólnikową notką zapowiadająca tematykę numeru na stronie internetowej pisma nie narzucaliśmy kierunku poszukiwań ani nie sugerowaliśmy zagadnień. Postanowiliśmy także nie kierować specjalnych, adresowanych do konkretnych osób zaproszeń. Numer układał się sam. Po drodze dochodziły artykuły, które znacznie poszerzyły ogląd tego, co nazywamy sztuka, a stawiając nowe pytania - zarówno o zakres obszarów przygarnianych, jak i o poszukiwanie języka(ów) opisu (a może lepiej powiedzieć: współtworzenia przez kreowanie komentarza działań artystycznych) - doprowadziły do powstania numeru poświęconego dramaturgii sztuki. Z autorskich zapisanych refleksji wyłoniła się bowiem swoista dramatografia - dramaturgia wyrastająca z aktów pisania odwołujących się do przedstawianych lub jedynie przywoływanych słownie materiałów wizualnych (brudnopisów, scen filmowych, obiektów plastycznych itp.). Kolejne artykuły pokazywały, że u podstaw wypowiedzi o sztuce tkwi rodzaj konstrukcji dramatycznej (oto rozgrywa się dramat reguł i formul, stylów i postaw, światopoglądów i metodologii).

Teksty o „sztuce bez granic”, które wypełniły bieżący numer, wytwarzaja - zgodnie z przyjęta zasadą dramaturgii pisma - obszary rozmaitych splątań odsłaniających możliwości sztuki, w której pojęcie granicy zniknę- 
ło. Myślenie o sztuce zostało zastapione myśleniem sztuką. Prezentowane teksty prowadzą nas ku przestrzeniom myślenia inkluzywnego, przygarniającego materie tak różnorodne, tak odmienne, że dopiero wtedy, gdy występują razem, tworza, niekiedy aż zaskakujące, nowe pola odniesienia współczesnych wymiarów sztuki. Myślimy więc choć przez chwilę regułami komputerowej „gry w Orwella” i przechodzimy krótki kurs „Rejsu”. Wczuwamy się w wyobraźnię mistyczek, przyglądamy się narracji osób transseksualnych, przyjmujemy perspektywę tworzenia i rozumienia sztuki przez artystów i odbiorców z wadami słuchu. Przepisujemy zachodnią kulturę westernu na język japońskich filmów o Ajnach. Mamy też teksty, które prowokuja do działań, zapraszaja: wyjdźmy na chwilę na ulice Irlandii, by poznać irlandzki busking, oglądajmy pomnik papieża Jana XXIII okiem poety, grajmy w komputerową „grę w Orwella”, pobądźmy chwilę na wysypisku odpadów technologicznych. Przyjrzyjmy się brudnopisom Kantora, literaturze bez granic, sztuce ciała, obrazu, rzeźby, przestrzeni. Wiele artykułów skupia się na, jak rzecz nazywam, dramaturgii pojęć: czym dla nas jest dziś literatura, jak rozumiemy archiwum, jaka jest rola brudnopisu, jak kształtuje nasz odbiór esej o sztuce, czy pojęcie kiczu wystarcza, czym jest kiczyzm. Równocześnie pojawiają się i są rozważane pojęcia antybinarne, jak płynność czy nierozstrzygalność, bądź redefiniowane kategorie, jak przestrzeń w refleksji Gilles'a Deleuze'a zobrazowana w sztuce Samuela Becketta. Myśląc sztuka, świat zobaczymy inaczej.

Nasza krytyczna refleksja każe nam z każdą chwila, z każdym artykułem zmieniać opcje, wchodzić w dialogi, ale jeszcze częściej wypróbowywać różne podejścia do przywoływanych zjawisk. Mamy więc refleksję kognitywistyczna, spojrzenia medioznawcze, powrót do semiologii, akcentowanie retoryki, zapis doznań mistycznych, przywoływanie genologii itp.

Staramy się patrzeć na problem obrazu czy przestrzeni nie tylko poprzez opozycję materialność/złudzenie, ale pokazywać niestabilność i anamorficzność jako cechę doświadczania migotliwej rzeczywistości ludzi i świata rzeczy.

Przeglądając prezentowaną serię artykułów (z niektórymi całkowicie się utożsamiając, z innymi chcąc polemizować, a jeszcze innym postawić różne pytania), utwierdziłam się $\mathrm{w}$ - wyrażanym przeze mnie od bardzo dawna przekonaniu, że zmierzamy w kierunku, z którego nie ma już odwrotu. Oto na naszych oczach zmienia się świat, a raczej nasz sposób podejścia do niego, przechodząc od wizji „tekstowego świata”, operującego kategorią zmiany (zmieniania granic), do „splątanego świata”, żywiącego się kategorią nietrwałej łączliwości (znikania granic). Pierwsza opcja zakłada, że ustalanie granic jest niezbędne w sztuce jako tekście (rozumianym w szerokiej skali definicji: od ujęć strukturalnych, semiologicznych, a nawet do poststruk- 
turalnych), druga opcja (dramaturgiczna, performatywna), choć ma wiele wspólnego w rodowodach z dekonstrukcja, zmienia sam sposób pojmowania granicy; operuje już nie tylko kategorią zacierania, wymazywania, śladu, ale, akcentując ruch i proces, kieruje się przede wszystkim zasadą anamorfozy. Jest tak i tak - równocześnie. Jakby powiedział Bolesław Leśmian (poeta widzący świat antybinarnie, więc zakładający na przykład możliwość istnienia stanu skupiającego w jednej chwili przeszłość, teraźniejszość i przyszłość) - „błysk niedobłysk na wybłysku”.

Jonathan Culler w swoim - jakkolwiek słowo to zabrzmi po cytacie z Leśmiana - błyskotliwym szkicu analizujaccym wiersz Roberta Frosta Sekret siedzi pokazał splątanie (zwykle przeciwstawianych sobie) zdań o charakterze konstatacji i performatywu. Mówiąc skrótowo - nie możemy operować skutecznie wypowiedzią performatywna, nie odnosząc jej do konstatującej, do sądu, który z kolei sami zbudowaliśmy, używając zdań o charakterze performatywnym. Czy nie przypomina to wstęgi Möbiusa? ${ }^{1}$. Czy nie mamy do czynienia z błędnym kołem dowodzenia, zwanego w logice dwuwartościowej reductio ad absurdum? A może absurd jest istotą naszego świata? Nie pierwsi myślimy przecież w taki sposób, jak Søren Kierkegaard, Albert Camus, Jean-Paul Sartre czy inni „filozoficzni absurdyści”... Naturę języka niebinarnie, ale zdarzeniowo pokazał między innymi Michaił Bachtin w Estetyce twórczości stownej ${ }^{2}$, który, polemizując z Ferdynandem de Saussure'em, zniósł granicę między językiem pojmowanym w kategoriach systemu jako langue a językiem traktowanym jako wypowiedź parole, ustanawiając nie tyle nową opozycję, ile przekreślając sam sens jej ustanawiania. O języku decydują zatem akty jego użycia. Język buduje nieopozycyjna wobec niego żywa mowa. Można by powiedzieć, że język stale się wydarza.

Nie niszczymy więc granic po to, by je ustawić gdzie indziej, ale usuwamy same zasady ustanawiania, które, jako nieistotne, pozostaną rozmytymi, chwilowymi, niejasnymi na zawsze. A nawet usuwamy całkowicie samo pojęcie granicy. Czy można żyć w świecie bez granic? Jeśli tkwimy w narzuconych, wdrukowanych, wyćwiczonych, przyjętych schematach - nie ma takiej możliwości, bo zawsze odnosić będziemy pojęcia do ich przeciwstawieństw, a tym samym - wyznaczać granice. Jeśli natomiast popatrzymy inaczej, odkryjemy w przedmiotach, zjawiskach i ludziach rodzaj, mówiąc Bachtinem, niewspółobecności, bycia splątanego z nieistnieniem.

Piękno i brzydota są tego jaskrawym przykładem. Umberto Eco, wydając dwa słynne tomy dotyczące opozycyjnych pojęć piękna i brzydoty, pokazał równocześnie coś wręcz przeciwnego - dwa osobne, wydawałoby się,

${ }^{1}$ J. Culler, Literatura w teorii, przekł. M. Maryl, Kraków 2013, s. 38-40, 190-193.

${ }^{2}$ M. Bachtin, Estetyka twórczości słownej, przeł. D. Ulicka, opracowanie przekładu i wstęp E. Czaplejewicz, Warszawa 1986. 
przeciwstawne tomy, w istocie nimi nie są ${ }^{3}$. Oglądając i czytając je jeden po drugim, niezauważalnie zaplątujemy się (omen nomen - splątanie!) w ich pozorne przeciwieństwo; im więcej wykonujemy ruchów, chcąc powrócić do jasnych podziałów, mocnych dychotomii, tym bardziej związujemy pojęcia opozycyjne razem, niwelując ich kontury, zacierając różnice. Piękno odpycha, brzydota zachwyca. Idą razem, splątują się, przejmując zwrotnie swoje cechy, ale równocześnie nie zlewają się całkowicie, nie osiagają - moim zdaniem - postaci amalgamatu. Patrzę na uliczny plakat zatytułowany Piękni ludzie. Widzę na przedstawionej twarzy uśmiech, wspaniały wyraz czystej, niezmąconej niczym radości, wręcz istotę szczęścia. Patrzę powtórnie i widzę niepełnosprawność, twarz osoby z zespołem Downa. Piękno radości odsłania piętno inności. Piętno naznaczającej wady pokazuje piękno zdolności szczerego odczuwania.

Myślenie antybinarne, oczywiste dla świata Dalekiego Wschodu, zaczyna powoli ogarniać i zarazem przekształcać świat Zachodu. Przyglądając się dyskusjom publicznym dotyczącym aktów splątania sfery sacrum i profanum, pola natury i kultury, obszarów tożsamości, ludzkich biografii itp., odnotowujemy coraz częściej argumentację eliminująca opozycyjność, która rodzi opory odbiorców-daltonistów, czyli ludzi niewidzących pełnej palety barw, tyle że w tym przypadku chodziłoby o szarość, o wszystkie odcienie szarości (pojmowanej jako rodzaj barwy mieszczącej w sobie brzegi, mówiąc językiem wiersza Różewicza, „nie kolorów”, czyli - czerni i bieli). Natura światła również ma charakter antybinarny - rozbite jego spektrum daje wielokolorową tęczę. Co zatem jest złudzeniem - jasne, jednolite światło czy wielobarwna tęcza? Często przywołuję myśl Szekspira ,jest tak, jak się Państwu zdaje”, czyli po prostu „Jak Wam się podoba”. Zwłaszcza że na niebie nad oceanem widziałam kiedyśs zachwycające zjawisko - podwójną tęczę.

Jak złudne sa wszelkie przeciwstawienia, pokazał nam wyraziście kamp. Co widzimy w performansach drag queen? ${ }^{4}$. Przebranie, kostium, grę czy autentyczne doświadczenie bycia innym/ą? Złudzenie bycia tym, kim chcecie nas zobaczyć? Czy może złudzenie bycia tym, za kogo uważaliśmy się całe życie? A może dostrzeżenie samej mocy dowolnego kreowania zjawisk przez elementy tworzonej fikcji? Czyż sztuka nie byłaby tym samym?

$\mathrm{Na}$ koniec chciałabym się zatrzymać nieco dłużej nad jednym z artykułów, kończącym się zdaniem, które można by paradoksalnie odnieść nie tylko do poruszanych w nim problemów sztuki i środowiska (przenikania się odpadów technologicznych i materii organicznej), ale szerzej do uczestnictwa w sztuce przekreślającej ujmowanie świata poprzez stosowanie

${ }^{3}$ Historia piękna, red. U. Eco, przeł. A. Kuciak, Poznań 2005. Historia brzydoty, red. U. Eco, przekł. zbiorowy, Poznań 2007.

${ }^{4}$ Kamp. Antologia przekładów, red. P. Czapliński, A. Mizerka, Kraków 2012. 
kategorii opozycji. Jego autorka, Diana Lelonek, pisze, że wobec trudności przezwyciężania ujęć binarnych dotychczasowy „[...] opis typu stanowisk od-przedmiotowych komponowany jest z dwóch podstawowych wyróżników typu materii od-śmieciowej i pierwotnego typu ekosystemu, jaki stał się miejscem śmieciowo-roślinnej transgresji”. I dalej stwierdza: „Prawdziwie nowa klasyfikacja zakłada całkowite odejście od nazewnictwa i form klasyfikacji opartych na dualizmach. Niemniej jednak jest to proces niezwykle trudny - co dowodzi, że bardzo mocno nasz system pojęciowy jest uwikłany w klasyczne rozróżnienie na to, co naturalne i kulturowe”.

Odpowiadając na pragnienie Autorki, by tworzyć nazewnictwo i formy klasyfikacji nieoparte na opozycjach binarnych, zaproponować można przyjęcie języka dramaturgii. Procesy zachodzące w sztuce (nie tylko w sztuce współczesnej, ale także w sposobie widzenia i ujmowania sztuki dawnej) chciałabym widzieć (zgodnie z Autorka) jako, nawiązując do teorii Bruno Latoura, grę sceniczną ludzkich i nie-ludzkich aktorów. Nie odwołuję się tutaj jednak ani do Latourowskiej teorii aktora-sieci, ani do dawnych toposów „teatru obrazu świata” czy „teatru figury świata”, ale do wprowadzanego tu w ich miejsce pojęcia „teatru splątanego świata”. Kwantowa terminologia mogłaby stać się punktem wyjścia do tworzenia nowych nazw określających różne zjawiska procesów splątania. Jesteśmy blisko fizyki, teatru i poezji. Wiele zjawisk w sztuce powstawało bowiem z rozmaitych zbitek pojęciowych, czego najlepszym przykładem jest nazwa japońskiego teatru kabuki (ka - pieśń, bu - taniec, ki - zręczność). Bo, jak pisze Kawatake Toshio, przywołując słowa Tsubouchi Shōyō, „kabuki to chimera”. Można by powiedzieć, że oto mamy liczne obiekty sztuki traktowane już nie jako artefakty, stabilne materie, ale chimery, „obiekty splątane”, których nie można opisać jednoznacznie jako żywych czy martwych, jak „żywe rzeczy”, należących do świata natury czy wytworów/odpadów technologii, jak „śmieciorośliny” itp., w których zaciera się także ich charakter podmiotowy i przedmiotowy. Oznacza to jednak jeszcze coś więcej - nie tylko, jak słusznie sugeruje Lelonek, nie można już tych obiektów opisywać w kategoriach binarnych, ale dodajmy także w kategoriach statycznych, jako artefaktów czy obiektów właśnie, ale trzeba - moim zdaniem - przenieść akcent na ich performatywny sposób istnienia. Inaczej mówiąc - nie da się opisać tych obiektów tylko w kategoriach bytów, ale trzeba spróbować pokazać scenariusz dramatyczny, który wytwarzaja, opisać rozwój ich dramaturgii. Można by pomyśleć, by w nazwach nie eksponować tylko cech (odwołanie się do fizykalnych kategorii estetycznych, jak chropowatość, gąbczastość,

${ }^{5}$ T. Kawatake, Kabuki: Baroque Fusion of the Arts, transl. by F. \& J. Connell Hoff, Tokyo 2006. Wydanie oryginalne o tytule Kabuki, Tokyo 2001. 
kłączastość, lepkość, gęstość itp.), ale podkreślać akcje i procesy (odwołanie się do performatywnych kategorii estetycznych, jak przenikanie, odkształcanie, wykorzystywanie, wrastanie, butwienie, oblepianie, chłonięcie, matowienie, obrastanie, omszenie itp.). Tak postępujac, wprowadzamy nowe kategorie estetyczne, które, odnosząc się do czynności, akcentują ich wymiar performatywny. Można by wręcz zapytać na przykład, jak działa i „co z nami robi" (jak na nas wpływa, jakie wywiera wrażenie, jakie uruchamia emocje, jaką ma siłę sprawcza) „śmiecioroślina”, traktowana jako chimera w „splątanym świecie” „naturotechnokultury”. Niektóre procesy opisywane przez Artystkę, jak przeistoczenie się gąbki w rodzaj kory, nie mają nazwy, chyba żeby mówić o ukorowieniu (analogicznie do ukorzenienia). Sa to jednak wartości tylko pozornie przeciwstawne: chociaż ukorzenienie wiąże się z życiem, a ukorowienie ze stawaniem się martwym, to jednak zmiana ta oznacza poświęcenie dokonane tylko po to, by żywy organizm bronić. Zachodzi ciekawy dramaturgiczny proces konieczności rozwoju języka na wzór dokonań poetyckich. „Obiekty splątane” odwzajemnią się pokazaniem dynamiki rozwoju ich hybrydowej natury. Inwencja nazewnicza należy już do dramaturgów, artystów i krytyków sztuki.

Przyglądając się zatem nie tylko przedmiotom i osobom, ale i kategoriom estetycznym oraz mechanizmom działania pojęć w sztuce, proponuję, w celu uchwycenia ich performatywnej natury, język opisu dramaturgii sztuki jako aktu splątania obiektów, podmiotów, mediów, procesów, zdarzeń.

\section{BIBLIOGRAFIA}

Bachtin M., Estetyka twórczości słownej, przeł. D. Ulicka, oprac. przekładu i wstęp E. Czaplejewicz, Warszawa 1986.

Culler J., Literatura w teorii, przekł. M. Maryl, Kraków 2013.

Historia brzydoty, red. U. Eco, przekł. zbiorowy, Poznań 2007.

Historia piękna, red. U. Eco, przeł. A. Kuciak, Poznań 2005.

Kamp. Antologia przekładów, red. P. Czapliński, A. Mizerka, Kraków 2012.

Kawatake T., Kabuki: Baroque Fusion of the Arts, transl. by F. \& J. Connell Hoff, Tokyo 2006.

Latour B., Splatajac na nowo to, co spoteczne. Wprowadzenie do teorii aktora-sieci, Kraków 2010. 
